\title{
Production of a novel probiotic date juice with anti-proliferative activity against Hep-2 cancer cells
}

\author{
Heba Sayed MOSTAFA ${ }^{1 *}$ (D), Marwa Rashad ALI ${ }^{1}$ (D), Reda Mahgoub MOHAMED ${ }^{1}$
}

\begin{abstract}
Date fruit is the ancient discovered and consumed fruit. Worldwide, Egypt is the largest producer of date. Besides its health benefits, many recent studies have proved its antioxidant, anticancer and anti-inflammatory effect. Currently, probiotic fermented fruit juices have a great attention especially for lactose intolerance patients. This study assessed the survival of two probiotics (Lactobacillus acidophilus and L. sakei) in the date juice. Phenolics characterization was performed by HPLC. Anti-proliferative activity of fermented juice against Caco-2 and Hep-2 cell lines was also evaluated. Under cold storage, L. sakei was still live for 2 weeks at $1.8 \times 10^{7} \mathrm{CFU} / \mathrm{mL}$. In contrast, L. acidophilus reduced from $5.2 \times 10^{6} \mathrm{CFU} / \mathrm{mL}$ to below the minimum value of probiotic products just after 1 week. L. sakie significantly multiplied the total phenols and antioxidant activity in the juice compared to the unfermented juice. Interestingly, probiotic date juice exhibited an antitumor activity against larynx cell lines (Hep-2) with no activity against Caco-2. Date juice was proved to be suitable for probiotic and as potential larynx anticancer juice. Therefore, the developed juice is recommended to contribute to the available probiotic foodstuffs.
\end{abstract}

Keywords: date juice; non-dairy probiotic product; phenolics multiplication; lactose intolerance; Hep-2 antitumor.

Practical Application: Probiotic fermented date juice with antitumor effect was created.

\section{Introduction}

Recently, the priorities of research are focused on developing functional foods and beverages to improve human health. The most widespread functional ingredient is probiotics (Guimaraes et al., 2020). In 2001, FAO and WHO debated the emerging field of probiotics and defining probiotics as "[...] live microorganisms which when administered in adequate amounts confer a health benefit on the host" (Hill et al., 2014, p. 506). The consumption of probiotics-enriched food becomes a popular trend due to the scientific evidence about its beneficial effect on the gut micro-flora (Rijkers et al., 2011). Currently, probiotics are widely added to dairy products (Mortazavian et al., 2011; Barros et al., 2020) as well as non-dairy foodstuffs (Shori, 2016). The high capacity of probiotics to provide health benefits is varied according to the probiotic lactic acid strain and the delivery food product (Zucko et al., 2020; Roobab et al., 2020). Probiotics can decrease the weight gain, waist circumference, serum glucose, insulin level and low density lipoprotein-cholesterol, oxidized products in the blood, inflammation markers; and increase glutathione and high-density lipoprotein-cholesterol (Ejtahed et al., 2019; Rezazadeh et al., 2019; Roshan et al., 2019; Salami et al., 2019). Probiotics also showed anti-obesity (Chen et al., 2011), gastrointestinal ecosystems improvement (Reddy \& Rivenson, 1993; Tang et al., 2016), anti-cancer (Kumar et al., 2012), anti-oxidative of the lungs, gut, and liver (Vasconcelos et al., 2019) and anti-hyperglycemic effect (Grom et al., 2020).

Cancer is the second cause of death all over the world that reached 9.6 million deaths in 2018. Approximately $70 \%$ of cancer deaths appear in low and middle-income countries. Nearly,
$30 \%$ of cancer deaths are due to several reasons such as: high BMI (body mass index), low intake of fruit and vegetable, lack of exercise, smoking, and alcoholism (World Health Organization, 2018). Colorectal cancer (Caco-2) is the third most common cancer in men and the second common cancer in women worldwide (Dallal et al., 2015). Recently, new cases suffered from larynx cancer $(0.8 \%$ of total cancer cases number) were also disclosed (World Health Organization, 2019). Probiotics and their metabolites exhibited an anti-cancer activity towards different kinds of cancer. Kwak et al. (2014) reported that, the traditional Korean fermented food by probiotic lactic acid bacteria (Weissella, Lactobacillus, Leuconostoc and Pediococcus species) are known to put down the activity of carcinogen-activating enzymes, such as nitroreductase, $\beta$-glucosidase, azoreductase, 7 - $\alpha$-dehydrogenase, and $\beta$-glucuronidase and inhibit or neutralize the cancer-causing agents and pathogenic microbes. On the other side, the water soluble peptides extracts obtained from buffalo and cow milk Cheddar (prepared by the action of Lactococcus lactis subsp. lactis and cremoris) demonstrated marked growth inhibition activity towards human lung (H-1299) (Rafiq et al., 2018a), colon (HT-29) (Rafiq et al., 2018b) and adenocarcinoma (HCT-116) cancer cell lines (Rafiq et al., 2020) by cell cycle arrest and extensive apoptosis induction.

Dairy products are the common food carrier for probiotics, but the consumption of these products is limited due to increment of vegetarianism and lactose intolerant individuals. Thus, the development of non-dairy probiotic products, including foods based on vegetables (Eliane et al., 2013), cereals (Yahyaoui et al., 2017) 
and fruit (White \& Hekmat, 2018; Campos et al., 2019) has been widely invented. The date palm (Phoenix dactylifera $\mathrm{L}$.), a tropical and subtropical fruit tree, which belongs to the family Palmae arecaceae is broadly grown around the world (El Sohaimy et al., 2015). Egypt is the world's largest producer $(1,590,414$ tons in 2017) according to FAOSTAT (Food and Agriculture Organization of the United Nations, 2017) and it produces about $20 \%$ of the total world production. Semi-dry date represents about 20.4\% of the total Egyptian production and Siwi date variety is one of semi-dry dates which represent about 16.9\% (Bekheet \& El-Sharabasy, 2019). Date fruit is rich in phytochemicals such as carotenoids, polyphenols (e.g., phenolic acids, isoflavons, lignans and flavonoids), tannins and sterols (Al-Alawi et al., 2017). It is considered a moderate source of riboflavin, niacin, pyridoxal and folate as $100 \mathrm{~g}$ of dates provide over $9 \%$ of the daily (RDA/AI) for adults (Baliga et al., 2011). Many studies have shown that date has antitumor activity as it can stimulate IFN- $\gamma \mathrm{m}$ RNA expression in cells and increases Th1 immune response (Karasawa et al., 2011; Tang et al., 2013). Date syrup was evaluated as additive to some probiotic dairy products such as milk (Al-Otaibi et al., 2013) and yoghurt (Aleid et al., 2018). However, no reports investigate nor the suitability of non-dairy date juice as a vehicle of probiotic bacteria or the effect of the fermented juice on cancer cell lines.

This study aimed to evaluate the influence of probiotic lactic acid bacteria (Lactobacillus acidophilus La5 and L. sakei NRRL 1917) fermentation on the physicochemical and sensory properties, phenols profile using HPLC, antioxidant power of the obtained date juice. Furthermore, in vitro antitumor activities of probiotic juice towards human larynx carcinoma (Hep-2) and colorectal cancer (Caco-2) cell lines were also tested.

\section{Materials and methods}

\subsection{Materials}

Dimethylsulphoxide (DMSO), RPMI-1640 medium, trypan blue, fetal bovine serum, penicillin/streptomycin antibiotic, Trypsin-EDTA, Folin-Ciocalteau, DPPH and phenolics standards were purchased from Sigma Aldrich Chemical Co. (St. Louis, Mo, USA).de Man Rogosa and Sharpe (MRS) medium was obtained from Merck (Darmstadt, Germany). The commercial minced date fruit (Phoenix dactylifera L. var. Siwi) was purchased from the local market and reserved at room temperature. Human tumor carcinoma cell lines (human colon cancer, Caco-2) and (human larynx carcinoma, Hep-2) that used in this study were obtained from the American Type Culture Collection (ATCC, Manassas, VA, USA). Cell lines were maintained by sub-culturing at the National Cancer Institute, Cairo, Egypt.

Two probiotic lactic acid bacteria (LAB) strains were used in this study i.e. Lactobacillus acidophilus La5 and Lactobacillus sakei NRRL 1917. They supplied from Chr. Hansen (Horsholm, Denmark) and the US Department of Agriculture, Northern Regional Research Laboratories (NRRL), respectively. LAB stock cultures were stored frozen at $-20^{\circ} \mathrm{C}$ in MRS medium (with $20 \%$ glycerol) and activated at $37^{\circ} \mathrm{C}$ in MRS medium before use. The numeration of the LAB cells after fermentation and during cold storage was performed by the standard plate count method with MRS agar after a proper dilution and expressed as $\log \mathrm{CFU} / \mathrm{mL}$.

\subsection{Preparation of inoculum and fermented date juice}

The bacterial cultures were grown separately at $37^{\circ} \mathrm{C}$ for $48 \mathrm{~h}$ in the MRS broth to reach $1.2 \times 10^{6} \mathrm{CFU} / \mathrm{mL}$ for L. acidophilus La5 and $1.0 \times 10^{7} \mathrm{CFU} / \mathrm{mL}$ for $L$. sakei, then cells were harvested by centrifugation at $4000 \mathrm{x} g$ for $5 \mathrm{~min}$ (Hermle, Z 300, Germany), washed twice then resuspended in sterilized distilled water. Subsequently, the minced date was mixed with distilled water and diluted to $18 \%$ TSS (initial pH 4.0). Diluted juice was packed in sterilized glass bottles and pasteurized at $85^{\circ} \mathrm{C}$ for $10 \mathrm{~min}$, cooled then inoculated with the inoculums $\left(4 \% \mathrm{v} / \mathrm{v}\right.$, inoculums/ juice) and anaerobically fermented at $37^{\circ} \mathrm{C}$ for further $48 \mathrm{~h}$. Viability of $L$. acidophilus La 5 and $L$. sakei were $7 \times 10^{6}$ and $2.2 \times 10^{8} \mathrm{CFU} / \mathrm{mL}$, respectively. Samples were taken after the fermentation process for chemical and microbiological experiments. The fermented juice bottles were refrigerated at $4{ }^{\circ} \mathrm{C}$ for 21 days just after the end of fermentation. The viable cell counts, $\mathrm{pH}$, acidity, reducing and total sugars, total phenolics and antioxidant activity of probiotic juice were determined weekly intervals of cold storage.

\subsection{Physicochemical analysis}

Total soluble solids, acidity, reducing and total sugar

Total soluble solids (TSS) of date juice were measured with a hand refractometer (Model DR-A1; Atago, Japan), and results were expressed as percent of total soluble solids (\%) in juice at $25^{\circ} \mathrm{C}$ (Khosravi et al., 2019). Total titratable acidity, expressed as $\mathrm{mg} / 100 \mathrm{~mL}$ lactic acid equivalents of organic acids, was determined by titrating the diluted date juice samples with $0.1 \mathrm{~N} \mathrm{NaOH}$. The $\mathrm{pH}$ measurement was accomplished by a pH-meter (Orion Research Incorporated, Boston, USA).

Concentration of reducing sugar in date juice was estimated by the dinitrosalicylic acid method (DNSA) at $540 \mathrm{~nm}$ using Spectrophotometer (Unico, UV2000, USA) according to Garriga et al. (2017). Whereas, the total sugar content was determined by Anthrone method at $630 \mathrm{~nm}$ according to More et al. (2018). Glucose was used as a standard for both methods.

\section{Total Phenolic Compounds (TPC)}

Fermented or unfermented date juice content of TPC was determined according to Folin-Ciocalteu method as described by Singleton \& Rossi (1965) with some modifications. Half $\mathrm{mL}$ of date juice was diluted with $12.5 \mathrm{~mL}$ water then, filtrated using filter paper No. 1. One $\mathrm{mL}$ of Folin-Ciocalteu reagent $(10 \%, \mathrm{v} / \mathrm{v})$ was added and after $5 \mathrm{~min}$ at room temperature, $0.8 \mathrm{~mL}$ of $20 \%(\mathrm{w} / \mathrm{v}) \mathrm{CaCO}_{3}$ was added to the mixture and vortexed, then allowed to stand for $1 \mathrm{~h}$ at room temperature in the darkness. The absorbance was measured at $760 \mathrm{~nm}$ using Spectrophotometer. The phenolic compound values were calculated using the standard curve of known concentrations of gallic acid solutions and expressed as milligram gallic acid equivalents (GAE)/100 $\mathrm{mL}$ date juice. 


\section{Antioxidant activity}

Antioxidant activity of the date juice was determined according to the method of Cam et al. (2014) with some modifications. The stock solution of DPPH was prepared as follows: $2.5 \mathrm{mg}$ of DPPH was dissolved in $100 \mathrm{~mL}$ methanol (about $0.0625 \mathrm{mM}$ ). $0.1 \mathrm{~mL}$ of date juice was diluted with $10 \mathrm{~mL}$ water, filtrated using Whatman No. 1 filter paper then, mixed with $3.9 \mathrm{~mL}$ of DPPH stock solution. The control sample was DPPH stock solution. The absorbance was measured using Spectrophotometer at $515 \mathrm{~nm}$ after incubation in the dark at room temperature for $30 \mathrm{~min}$. The Antioxidant activity as inhibition percent was calculated according to the following Equation 1:

Inhibition $(\%)=\frac{A_{\text {control }}-A_{\text {sample }}}{A_{\text {control }}} \times 100$

\subsection{Phenols characterization}

High-Performance Liquid Chromatography (HPLC) was used to identify the phenolic compounds in fermented and unfermented (control) date juice after 2 weeks of cold storage. HPLC analyzed with Agilent 1260 infinity HPLC series (Agilent, USA), equipped with a quaternary pump, a Zorbax Eclipse plus C180 column $100 \times 4.6$ mm i.d., (Agilent Technologies, USA), operated at $30{ }^{\circ} \mathrm{C}$. The separation was carried out using a triple linear elution gradient: A)- HPLC grade water $0.2 \% \mathrm{H}_{3} \mathrm{PO}_{4}(\mathrm{v} / \mathrm{v})$, B) - methanol and C)- acetonitrile. The injected volume was $20 \mu \mathrm{L}$. The wavelength of the VWD detector was $284 \mathrm{~nm}$. 24 polyphenol standards such as: kampherol, rutin, gallic acid, catechol, $p$ - hydroxyl benzoic acid, caffeine, vanillic acid, caffeic acid, syringic acid, vanillin, $p$-coumaric acid, ferulic acid, ellagic, benzoic acid, $o$-coumaric acid, salicylic acid, chlorgenic and cinnamic acid were used for identification and quantification of the phenolic compounds. The identification of each phenolic compound was done by comparing its peak area (Supplementary material 1) with the calibration curve.

\subsection{Sensory evaluation}

Sensory characteristics including color, sweetness, sourness, odor, consistency or smoothness and overall acceptability were evaluated by 40 untrained panelists of the Food Science Department (20 females and 20 males, aged 25 to 40 y), Cairo University. A 9-point Hedonic scale (0-2 = dislike extremely, 3-4 = dislike slightly, 5 = fair, 6-8 = like moderately, and $9=$ excellent) was utilized for such purpose. The rejection limit for the sample recorded 6 during the storage period. The date juice samples were served at room temperature in $50 \mathrm{~mL}$ glass cups at zero time and after 1, 2 and 3 weeks of cold storage (Ali, 2018).

\subsection{Cytotoxicity effect on human cancer cell lines}

\section{Cell line culture}

RPMI-1640 medium was used for culturing and maintenance of the human tumor cell lines. After filter sterilization $(0.22 \mu \mathrm{m})$, the medium was supplemented with $1 \%$ penicillin/streptomycin (100 U/mL penicillin and $2 \mathrm{mg} / \mathrm{mL}$ streptomycin) and $10 \%$ of fetal bovine serum (FBS).

\section{Antitumor effect of fermented date juice}

The cytotoxicity was carried out using Sulphorhodamine-B (SRB) assay according to Vichai \& Kirtikara (2006). Cells were seeded in 96-well microtiter plates (at initial concentration, $3 \times 10^{3}$ cell/well) in $150 \mu \mathrm{L}$ fresh medium and allowed to attach the plates. Firstly, fermented and unfermented date juice samples (after 2 weeks of cold storage) were freeze dried (at $-40^{\circ} \mathrm{C}$ by Snijders Scientific, Holland). Different concentrations $(0,62.5,125,250,500 \mu \mathrm{L} / \mathrm{mL})$ of juice were added to the plates and incubated for $48 \mathrm{~h}$. The cells were fixed with $50 \mu \mathrm{L}$ cold trichloroacetic acid ( $10 \%$ final concentration) for $1 \mathrm{~h}$ at $4{ }^{\circ} \mathrm{C}$. The plates were washed with distilled water using automatic washer (Tecan, Germany) and stained with $50 \mu \mathrm{L}$ SRB dye $(0.4 \%$ dissolved in $1 \%$ acetic acid for $30 \mathrm{~min}$ at room temperature). The plates were washed with acetic acid (1\%) then air-dried. The dye was solubilized with $100 \mu \mathrm{L} /$ well of $10 \mathrm{M}$ Tris buffer ( $\mathrm{pH} 10.5$ ) and the absorbance of each well was measured spectrophotometrically at $570 \mathrm{~nm}$ with the ELISA microplate reader (Sunrise Tecan reader, Germany). The mean background absorbance was automatically subtracted and the mean values of each juice concentration were calculated. The percentage of cell survival was calculated by the following Formula 2:

Surviving fraction $=$ OD $($ treated cells $) /$ OD $($ control cells $)$

The $\mathrm{IC}_{50}$ values (the concentrations of resveratrol required to produce $50 \%$ inhibition of cell growth) were also calculated.

\subsection{Statistical analysis}

The experiments were repeated three times (means $=3$ ) and the pooled data were subjected to one-way analysis of variance (ANOVA) with Co-stat software. The Duncan's test at $p<0.05$ was used to compare means among treatments during storage period.

\section{Results and discussion}

\subsection{Viability of probiotic bacteria, acidity and $\mathrm{pH}$ during cold storage}

Based on existing standards and from a health view-point, it is very important to retain the viability and functional activity of probiotic strains throughout the shelf life of the product (Granato et al., 2010). The effect of cold storage (at $4{ }^{\circ} \mathrm{C}$ ) for 3 weeks on the viability of LAB, acidity and $\mathrm{pH}$ of fermented date juice is indicated in Table 1.

Both studied LAB strains in fermented date juice remained viable for three weeks under cold storage. That may be correlated to the high content of $\beta$-glucan in dates that protects LAB during refrigeration as noted by Perricone et al. (2015). Results demonstrated that Lactobacillus sakei cells reached $2.25 \times 10^{8} \mathrm{CFU} / \mathrm{mL}$ after incorporation and fermentation in date juice and still survive for 2 weeks under cold storage $\left(1.8 \times 10^{7} \mathrm{CFU} / \mathrm{mL}\right)$ even with low $\mathrm{pH}$. It decreased 3 logarithmic orders after the $3^{\text {rd }}$ week; that probably due to cold temperature or organic acids accumulation. On the other hand, viable cells of L. acidophilus reduced from $5.2 \times 10^{6} \mathrm{CFU} / \mathrm{mL}$ to below the minimum accepted value $\left(10^{6} \mathrm{CFU} / \mathrm{mL}\right)$ of probiotic products just after 1 week storage. After that, the cell viability was stable at $10^{4}$ 
Table 1. Viability of L. acidophilus and L. sakei, acidity and $\mathrm{pH}$ of fermented and unfermented date juice during refrigerated storage at $4{ }^{\circ} \mathrm{C} \pm \mathrm{SD}$.

\begin{tabular}{|c|c|c|c|c|c|c|c|c|}
\hline \multirow{2}{*}{$\begin{array}{c}\text { Time } \\
\text { (week) }\end{array}$} & \multicolumn{2}{|c|}{$\begin{array}{c}\text { Viability } \\
(\log \mathrm{CFU} / \mathrm{mL})\end{array}$} & \multicolumn{3}{|c|}{$\begin{array}{c}\text { Acidity } \\
(\%)\end{array}$} & \multicolumn{3}{|c|}{$\mathrm{pH}$} \\
\hline & L. acidophilus & L. sakei & L. acidophilus & L. sakei & Control & L. acidophilus & L. sakei & Control \\
\hline zero & $6.81 \pm 0.11^{\mathrm{aB} *}$ & $8.35 \pm 0.05^{\mathrm{aA}}$ & $0.57 \pm 0.05^{\mathrm{bA}}$ & $0.45 \pm 0.05^{\mathrm{bB}}$ & $0.28 \pm 0.08^{\mathrm{bC}}$ & $4.33 \pm 0.06^{\mathrm{aB}}$ & $4.26 \pm 0.06^{\mathrm{aB}}$ & $6.06 \pm 0.06^{\mathrm{bA}}$ \\
\hline 1 & $5.10 \pm 0.03^{\mathrm{bB}}$ & $7.82 \pm 0.07^{\mathrm{bA}}$ & $0.69 \pm 0.05^{\mathrm{aA}}$ & $0.60 \pm 0.01^{\mathrm{aB}}$ & $0.27 \pm 0.00^{\mathrm{bC}}$ & $3.96 \pm 0.06^{\mathrm{bC}}$ & $4.13 \pm 0.06^{\mathrm{bB}}$ & $6.30 \pm 0.10^{\mathrm{aA}}$ \\
\hline 2 & $4.79 \pm 0.04^{\mathrm{cB}}$ & $7.25 \pm 0.02^{\mathrm{cA}}$ & $0.75 \pm 0.05^{\mathrm{aA}}$ & $0.63 \pm 0.06^{\mathrm{aB}}$ & $0.33 \pm 0.05^{\mathrm{bC}}$ & $3.76 \pm 0.06^{\mathrm{cC}}$ & $4.03 \pm 0.06^{\mathrm{bC}}$ & $6.10 \pm 0.17^{\mathrm{abA}}$ \\
\hline 3 & $4.32 \pm 0.02^{\mathrm{dB}}$ & $5.71 \pm 0.12^{\mathrm{dA}}$ & $0.72 \pm 0.01^{\mathrm{aA}}$ & $0.65 \pm 0.06^{\mathrm{aA}}$ & $0.45 \pm 0.00^{\mathrm{aB}}$ & $3.43 \pm 0.06^{\mathrm{dC}}$ & $3.66 \pm 0.05^{\mathrm{cB}}$ & $5.73 \pm 0.06^{\mathrm{cA}}$ \\
\hline
\end{tabular}

Samples of date juice were fermented at $37{ }^{\circ} \mathrm{C}$ for 2 days (zero time) then stored at $4{ }^{\circ} \mathrm{C}$ for 3 weeks; ${ }^{*}$ The experimental values (means and standard deviations for $\mathrm{n}=3$ ) with capital letters are significantly different between columns, while small letters between rows.

Table 2. Estimated TSS \% of fermented and unfermented date juice during refrigerated storage at $4{ }^{\circ} \mathrm{C} \pm \mathrm{SD}$.

\begin{tabular}{cccc}
\hline Time & \multicolumn{3}{c}{ TSS \% } \\
\cline { 2 - 4 } (week) & L. acidophilus & L. sakei & Control \\
\hline zero & $18.45 \pm 0.00^{\mathrm{aC} *}$ & $18.60 \pm 0.28^{\mathrm{aB}}$ & $18.80 \pm 0.00^{\mathrm{aA}}$ \\
1 & $18.35 \pm 0.00^{\mathrm{bB}}$ & $18.40 \pm 0.07^{\mathrm{bB}}$ & $18.80 \pm 0.14^{\mathrm{aA}}$ \\
3 & $18.15 \pm 0.21^{\mathrm{cD}}$ & $18.25 \pm 0.07^{\mathrm{cC}}$ & $18.75 \pm 0.42^{\mathrm{aA}}$ \\
& $17.80 \pm 0.00^{\mathrm{dC}}$ & $18.00 \pm 0.00^{\mathrm{dB}}$ & $18.75 \pm 0.49^{\mathrm{aA}}$ \\
\hline
\end{tabular}

Samples of date juice were fermented at $37^{\circ} \mathrm{C}$ for 2 days (zero time) then stored at $4{ }^{\circ} \mathrm{C}$ for 3 weeks; ${ }^{*}$ The experimental values (means and standard deviations for $\mathrm{n}=3$ ) with capital letters are significantly different between columns, while small letters between rows.

Table 3. Estimated total and reducing sugar $(\mathrm{g} / 100 \mathrm{~mL})$ of fermented and unfermented date juice during refrigerated storage at $4{ }^{\circ} \mathrm{C} \pm \mathrm{SD}$.

\begin{tabular}{|c|c|c|c|c|c|c|}
\hline \multirow{2}{*}{$\begin{array}{l}\text { Time } \\
\text { (week) }\end{array}$} & \multicolumn{3}{|c|}{ Total sugar $(\mathrm{g} / 100 \mathrm{~mL})$} & \multicolumn{3}{|c|}{ Reducing sugar $(\mathrm{g} / 100 \mathrm{~mL})$} \\
\hline & L. acidophilus & L. sakei & Control & L. acidophilus & L. sakei & Control \\
\hline zero & $14.50 \pm 0.00^{\mathrm{aC}}$ & $15.20 \pm 0.00^{\mathrm{aB}}$ & $16.20 \pm 0.00^{\mathrm{aA}}$ & $11.90 \pm 0.00^{\mathrm{aC}}$ & $12.60 \pm 0.00^{\mathrm{aB}}$ & $13.49 \pm 0.01^{\mathrm{aA}}$ \\
\hline 1 & $12.03 \pm 0.01^{\mathrm{bC}}$ & $13.05 \pm 0.07^{\mathrm{bB}}$ & $16.18 \pm 0.05^{\mathrm{aA}}$ & $11.05 \pm 0.07^{\mathrm{bC}}$ & $11.45 \pm 0.07^{\mathrm{bB}}$ & $13.49 \pm 0.07^{\mathrm{aA}}$ \\
\hline 2 & $11.75 \pm 0.07^{\mathrm{cC}}$ & $12.80 \pm 0.00^{\mathrm{cB}}$ & $16.05 \pm 0.07^{\mathrm{aA}}$ & $10.88 \pm 0.07^{\mathrm{cB}}$ & $11.00 \pm 0.00^{\mathrm{cB}}$ & $13.15 \pm 0.01^{\mathrm{bA}}$ \\
\hline 3 & $11.60 \pm 0.00^{\mathrm{dC}}$ & $12.50 \pm 0.00^{\mathrm{dB}}$ & $15.50 \pm 0.21^{\mathrm{bA}}$ & $10.50 \pm 0.00^{\mathrm{dC}}$ & $10.90 \pm 0.00^{\mathrm{dB}}$ & $12.89 \pm 0.21^{\mathrm{cA}}$ \\
\hline
\end{tabular}

Samples of date juice were fermented at $37^{\circ} \mathrm{C}$ for 2 days (zero time) then stored at $4{ }^{\circ} \mathrm{C}$ for 3 weeks. The experimental values (means and standard deviations for $\mathrm{n}=3$ ) with capital letters are significantly different between columns, while small letters between rows.

for the next 2 weeks. This decline may be due to the decrease in the $\mathrm{pH}$ from 4.33 to 3.43 after 3 weeks. Sheehan et al. (2007) reported that low $\mathrm{pH}$ juices, with range of $\mathrm{pH}$ between 2.5 and 3.7, cause an increase in cells sensitivity to stressful conditions. Viability of probiotic lactic acid bacteria in fermented fruits or vegetables juices depends on many factors such as: the nutrients content, $\mathrm{pH}$ and acidity. The effect of the refrigerated storage on the viability of probiotics has been studied by many researchers. Viability of $L$. case $i$ in fermented sonicated pineapple juice maintained higher than $10^{6} \mathrm{CFU} / \mathrm{mL}$ throughout the cold storage for 6 weeks (Costa et al., 2013). However, Daneshi et al. (2013) studied the viability in milk/carrot juice and they observed that all studied LAB strains attained viable cell numbers reduction of less than $1 \log \mathrm{CFU} / \mathrm{mL}$. L. acidophilus La5 showed a stable level of viable cells ( $98.8 \%$ viability) during storage over 20 days. The viability of other strains including B. lactis BB 12, L. rhamnosus and L. plantarum was $91.9,90.1$ and $88 \%$, respectively. On the other hand, Karbasi et al. (2015) noticed that L. acidophilus survived above $10^{6} \mathrm{CFU} / \mathrm{mL}$ for 4 weeks while L. rhamnosus reduced below this value after 2 weeks in cold fermented pomegranate juice. Also, L. rhamnosus GR-1 reached viable counts of at least $10^{7} \mathrm{CFU} / \mathrm{mL}$ in all fruit juice samples (apple cider, orange, and grape) that tested by White \& Hekmat (2018) during cold storage. Only the orange juice samples did not have a significant difference $(p<0.05)$ in mean microbial counts over 30 days of storage.

Results in Table 1 also showed a significant $(p<0.05)$ decrease in $\mathrm{pH}$ values with a simultaneous increase in acidity in juice incorporated L. acidophilus in compared to control juice.
Meanwhile, it could be observed that $L$. sakei decreased the $\mathrm{pH}$ after 1 week to 4.13 and remained with no significant difference for the next two weeks. During the cold storage of control sample (without $\mathrm{LAB}$ ), $\mathrm{pH}$ did not show significant change until the second week, but it decreased to 5.73 in $3^{\text {rd }}$ week. The acidity increase was also considerably higher in L. acidophilus (103\%) than L. sakei (60\%) after the fermentation in comparison to the unfermented juice. Acidity was stable with no significant difference after 1 week of storage in both probiotic fermented juices. These findings are agreed with Mohan et al. (2013) who studied the probiotic tomato juice and found that the acidity increased to $0.65 \%$ or higher.

\subsection{Estimated TSS \%}

Total soluble solids (\%) of the date juice significantly decreased from 18.45 to $17.8 \%$ and from 18.6 to $18 \%$ in fermented juice samples by L. acidophilus and L. sakei, respectively during the storage period (Table 2). In contrast, the control sample recorded no-significant change $(p<0.05)$ in TSS during the refrigerated storage. The sugars consumption and the formed acids during fermentation process by L. acidophilus and L. sakei are the main reasons of TSS reduction during storage.

\subsection{Estimated total and reducing sugar}

Table 3 revealed that; Lactobacillus requires sugar for growth and as the fermentation continues, the sugar content of samples declined gradually. Initially total sugar in control juice 
(unfermented juice) was $16.20 \mathrm{~g} / 100 \mathrm{~mL}$ which was significantly decreased in fermented juice to 14.50 and $15.20 \mathrm{~g} / 100 \mathrm{~mL}$ by $L$. acidophilus and $L$. sakei, respectively after the fermentation. The observed differences between L. acidophilus and L. sakei in sugar content may be due to the ability of $L$. sakei to produce exo-polysaccharides (Ruas-Madiedo \& De los Reyes-Gavilan, $2005)$. Both the total sugar content significantly reduced during the cold storage by $20 \%$ and $17.8 \%$ of fermented juice by $L$. acidophilus and $L$. sakei, respectively. On the other side, reducing sugar content reduced by $11.8 \%$ and $13.5 \%$ after 3 weeks of cold storage in fermented juice by L. acidophilus and L. sakei, respectively.

\subsection{Effect of the fermentation and cold storage on concentration and profile of the phenolic compounds}

The change in the total phenolic compounds concentration (TPC) of the fermented and unfermented (control) date juice during cold storage for 3 weeks is shown in Figure 1. There was no significant difference $(p<0.05)$ between TPC concentrations for all date juice samples at zero time (after $48 \mathrm{~h}$ of fermentation process at $37^{\circ} \mathrm{C}$ ) which ranged between $136.41-156.07 \mathrm{mg} / 100 \mathrm{~mL}$ juice. After 2 weeks of the refrigerated storage, there was no change in TPC content of the control sample $(137.26 \mathrm{mg} / 100 \mathrm{~mL}$ date juice). In contrast, the fermentation using L. acidophilus or L. sakei, impacted a great increase (duplicate the concentration of TPC) which reached to 392.30 and $399.02 \mathrm{mg} / 100 \mathrm{~mL}$, respectively which considered the highest concentration reached among the storage intervals. Pereira et al. (2017) noted that, in different fruit juices, lactic acid bacteria can synthesize varied phenolic compounds depend on the food composite and the applied strain. Several studies recorded that, the levels of antioxidant compounds, such as polyphenols are increased due to the fermentation by the lactic acid bacteria (Wu et al., 2011; Dimitrovski et al., 2015). For example, phenolic compounds increased by $L$. casei fermentation of cashew apple juice that conferring more health benefits to that functional juice (Pereira et al., 2013). Also, Pontonio et al. (2019) reported that, the fermentation process with L. plantarum of pomegranate juice increased the concentration of phenolics which improved the antioxidant activity percent more than $40 \%$ compared to the unfermented pomegranate juice.

Table 4 represents the quantity of the identified phenolic compounds of probiotic date juice after two weeks of cold storage as estimated by HPLC. A total of 19 phenolic acids was identified and quantified in the fermented date juice meanwhile; only 15 phenolic acids were identified and quantified in unfermented date juice. Among the phenolic acids, kampherol and gallic acid were identified as the most dominant, recording for the highest percentage of $54.4,66.6 \%$ and $14.56,10.86 \%$ in date juice fermented by $L$. acidophilus and L. sakei, respectively. On the other hand, the most dominant phenolic acids in unfermented juice (control) were ellagic, rutin and benzoic acid which recorded the highest percentage of $24.72,23.62$ and $18.05 \%$, respectively. These results are in accordance with Gan et al. (2016) and Kwaw et al. (2018) who observed the ability of Lactobacillus strains for increasing the TPC concentration in juice during the fermentation process. It was known that the fermentation process causes the releasing of

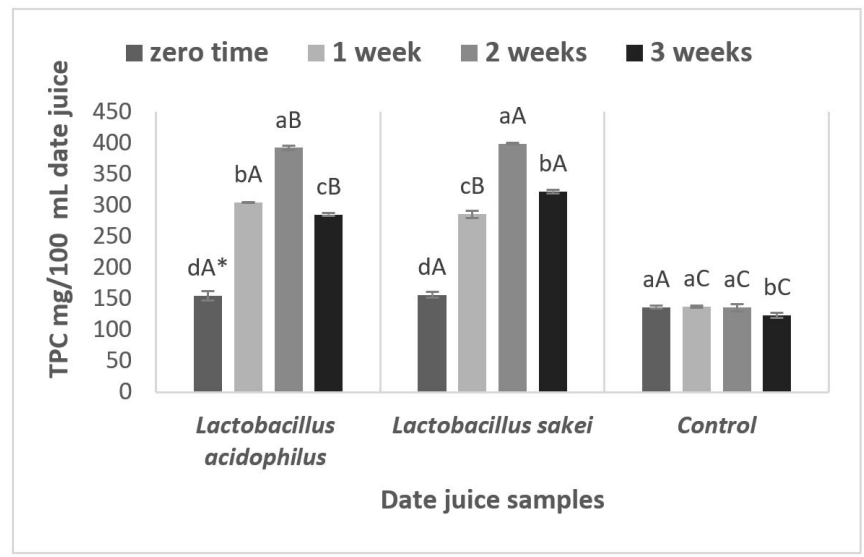

Figure 1. Total phenolic compounds (TPC) of fermented and unfermented (control) date juice during refrigerated storage at $4{ }^{\circ} \mathrm{C}$ for 3 weeks. ${ }^{\star}$ Capital letters indicate significant differences (Duncan's test, $p<0.05$ ) between the samples in each storage time, and small letters indicate significant differences during the storage period in each sample.

Table 4. The quantity of the identified phenolic compounds $(\mathrm{mg} / \mathrm{mL})$ in fermented and unfermented date juice (control) after refrigerated storage at $4{ }^{\circ} \mathrm{C}$ for 2 weeks as estimated by HPLC.

\begin{tabular}{cccc}
\hline \multirow{2}{*}{ Phenolic compound } & \multicolumn{2}{c}{ Fermented juice } & \multirow{2}{*}{ Control } \\
\cline { 2 - 3 } & L. acidophilus & L. sakei & - \\
\hline Pyrogallol & - & - & - \\
Quinol & 1.58 & 0.40 & - \\
Gallic acid & 14.56 & 10.86 & 3.55 \\
Catechol & 4.03 & 3.89 & - \\
p-Hydroxy benzoic acid & 6.24 & 4.45 & 3.76 \\
Caffeine & 0.85 & 0.39 & 0.28 \\
Chlorgenic & 0.97 & 0.60 & 0.37 \\
Vanillic acid & 1.86 & 0.74 & 0.27 \\
Caffeic acid & 0.21 & 0.14 & 0.13 \\
Syringic acid & 0.30 & 0.25 & 0.18 \\
Vanillin & 2.15 & 1.84 & 0.59 \\
p- Coumaric acid & - & - & 0.59 \\
Ferulic acid & 0.42 & 0.29 & 0.31 \\
Benzoic acid & - & - & 18.05 \\
Rutin & 1.78 & 1.23 & 23.62 \\
Ellagic & 1.87 & 0.85 & 24.72 \\
o-Coumaric acid & 0.68 & 0.49 & 0.12 \\
Salicylic acid & - & - & - \\
Cinnamic acid & - & - & - \\
Myricetin & 4.12 & 3.48 & 3.49 \\
Quercitin & 0.63 & 0.66 & - \\
Rosemarinic & 1.26 & 1.29 & - \\
Neringein & 3.42 & 3.02 & - \\
Kampherol & 54.40 & 66.64 & - \\
\hline
\end{tabular}

Each phenolic compound was identified by comparing its peak area (supplementary material) with the calibration curve.

microbial enzyme which producing higher chemical compounds from the plant such as flavonoids, tannin, alkaloids, and phenylpropanoid (Nazarni et al., 2016). Also, the fermentation process by Lactobacillus strains contributes to the simple 


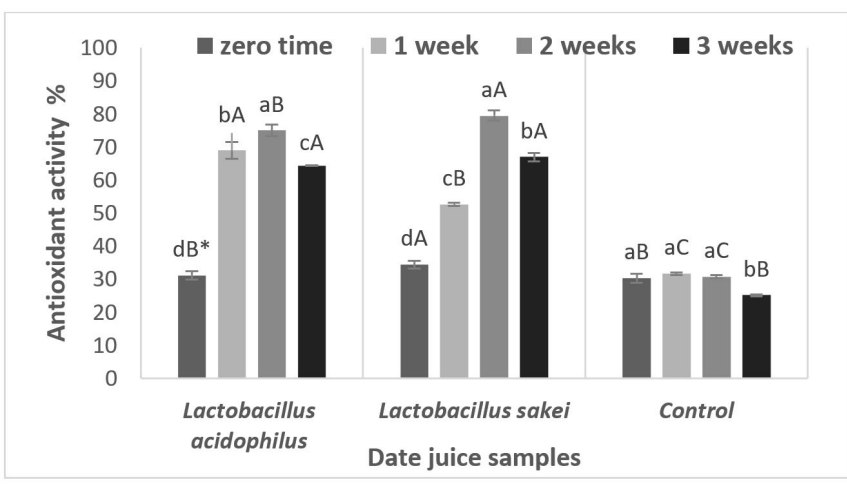

Figure 2. Antioxidant activity $\%$ of fermented and unfermented (control) date juice during refrigerated storage at $4{ }^{\circ} \mathrm{C}$ for 3 weeks. ${ }^{*}$ Capital letters indicate significant differences (Duncan's test, $p<0.05$ ) between the samples in each storage time, and small letters indicate significant differences during the storage period in each sample.

conversion and de-polymerization of phenolic compounds with the high molecular weight by poly-phenoloxidase (Othman et al., 2009). Moreover, natural fermentation using lactic acid bacteria induces the $\mathrm{pH}$ reduction thus; several implicated enzymes in the complex polyphenols hydrolysis were activated resulting in the active, simpler and higher polyphenols (Wijayanti et al., 2017). The concentration of TPC was significantly decreased after 3 weeks of storage time in all samples and that may be due to the decreasing of cell viability. Hashemi \& Mahmoodi (2017) reported that phenolic compounds can be decreased during storage due to the degradation occurred by enzymes and chemical reactions. Furthermore, the stability of phenolic compounds depends on pH (Kwaw et al., 2017) therefore; the $\mathrm{pH}$ decrease in fermented juice could be the cause of phenol stability. It can be concluded that, the fermented date juice had a high content of phenolic compounds than unfermented juice (control). Samples after 2 weeks of refrigerated storage were chosen for testing the antitumor effect as it exhibited the highest phenolic content.

\subsection{Effect of the fermentation and cold storage on the antioxidant activity $\%$}

Antioxidant activity of the fermented and unfermented date juice samples was determined by DPPH and presented in Figure 2. The illustrate results revealed the positive effects of lactic acid fermentation process on the antioxidant activity indicated by the increase in the inhibition of DPPH. There is no significant difference in antioxidant activity of unfermented (control) date juice sample during cold storage for 2 weeks, which ranged between 30.3 to $30.7 \%$. Meanwhile, the antioxidant activity of fermented date juice was higher than the control sample and reached the maximum after 2 weeks of cold storage. It recorded $75.03 \%$ in fermented date juice using $L$. acidophilus and $79.46 \%$ in fermented date juice using L. sakei. These results are in accordance with Zhang et al. (2012) who noticed the change in antioxidant activity after fermentation process that might be affected by the bacterial strain. Marazza et al. (2009) observed that the lactic acid bacteria producing $\beta$-glucosidase (including
Lactobacillus acidophilus, L. casei and L. plantarum) has the ability to increase the aglycone during the fermentation process which act as an antioxidant. The results indicate a decrease in antioxidant activity in all samples after 3 weeks of cold storage, it probably due to the reduction of TPC in date juice which strongly correlated with the antioxidant activity.

\subsection{Sensory evaluation}

The observed variation of sensory evaluation scores during cold storage for 3 weeks of unfermented (control) and fermented date juice are presented in Figure 3A, B, C and D.

All date juice samples have scores greater than the rejection limit (6) during the storage period ( 3 weeks), except the color of the control sample at the end of the storage time (score=5.57). It may be due to the chemical reactions or microbial growth occurred during the storage. The results indicated that lactic acid fermentation impacted on the color and taste (sweetness and sourness) of date juice during storage. Those results are in accordance with Kwaw and co-workers (2017) who referred to the correlation between the phenolic compounds and organoleptic properties of food especially TPC that directly affected the color and flavor. That might be referred to duplicate TPC percent formed by fermentation with both strains during the cold storage compared to the unfermented juice. Also, as mentioned before there was a significant decrease in $\mathrm{pH}$ during storage in fermented date juice sample than control, which creates a great and acceptable flavor due to the balance, occurred between sweet and sour taste. The overall acceptability of fermented date juice was evaluated by the panelists with scores slightly significant than unfermented juice, during the cold storage.

\subsection{Anticancer effects of probiotic date juice}

Substantial research using human cancer cells/cell lines has demonstrated that probiotics possess anti-proliferative activities in these cells (Yu \& Li, 2016). To investigate the anticancer effects of probiotic fermented date juice, two types of human cancer cell lines (Caco-2 and Hep-2) were treated with the freeze dried date juice samples after 2 weeks of cold storage at several concentrations. There were evidence of $50 \% \mathrm{Hep}-2$ cell death at 315 and $317 \mu \mathrm{l} / \mathrm{mL}$ after treating with date juice fermented with $L$. acidophilus and $L$. sakei, respectively that was significantly different from the non-treated cells $(p<0.05)$ and control juice. It may be correlated to the higher content of polyphenols and antioxidant activity than the control juice that plays a significant role in cancer control (Rahmani et al., 2014). In contrast; there is no cytotoxicity effect on Caco-2 cell lines observed by date juice fermented with both strains up to $500 \mu \mathrm{l} / \mathrm{mL}$. These results suggest that date juice fermented by both Lactobacillus strains (acidophilus and sakei) may be preferable as natural and safe laryngeal cancer therapeutic agent. The anticancer activities of various LAB strains including Lactobacillus, Bifidobacterium and Lactococcus have been previously confirmed (Choi et al., 2006; Azam et al., 2014). 

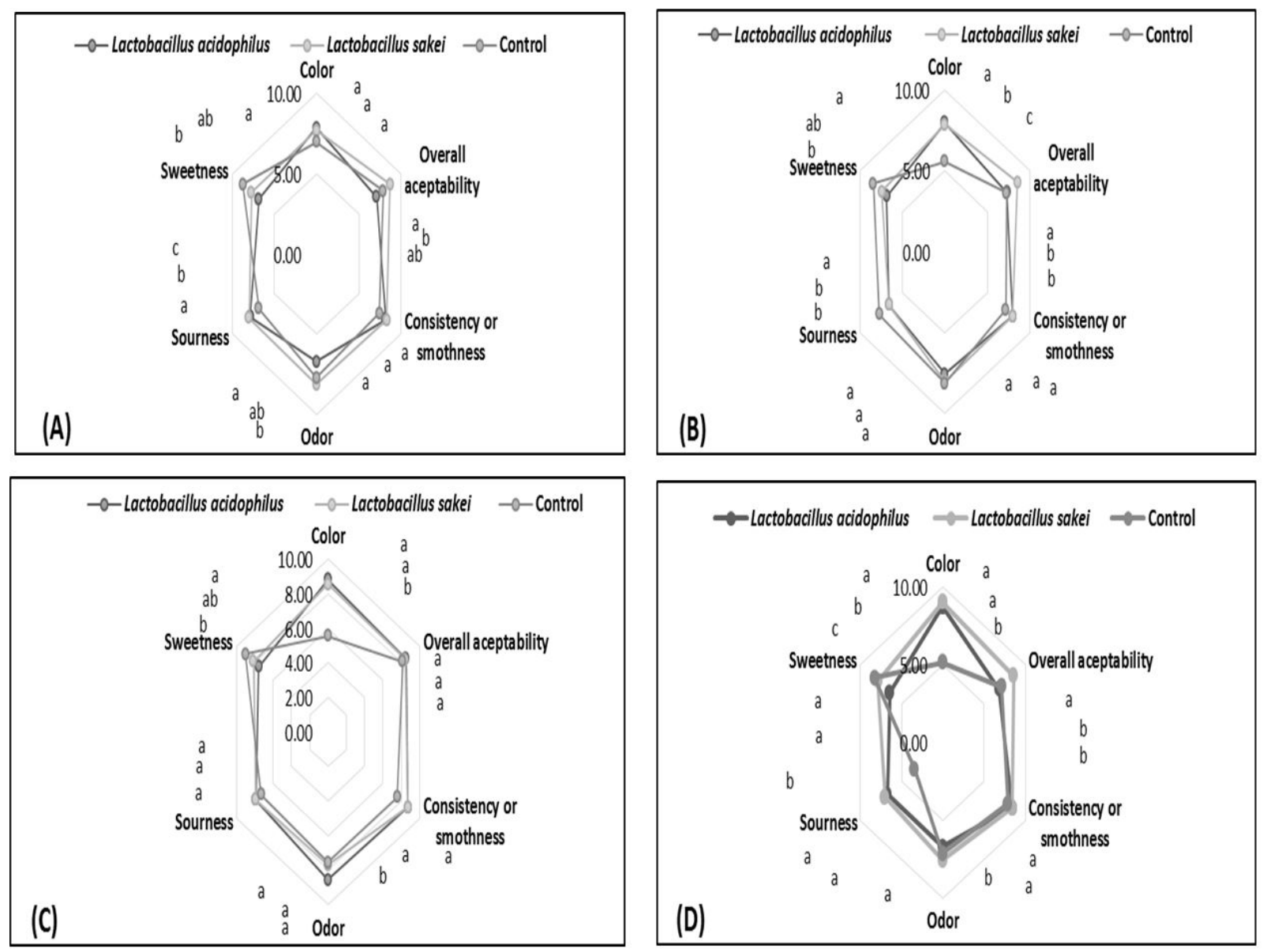

Figure 3. Sensory evaluation of fermented and unfermented date juice (control) date juice during refrigerated storage at $4{ }^{\circ} \mathrm{C}$ for 3 weeks. (A) zero time; (B) 1-week; (C) 2-weeks; (D) 3-weeks. Means $(\mathrm{n}=40)$ followed by different letters indicate significant differences between samples in each storage time.

\section{Conclusion}

The fermented date juice developed in this study could provide the consumers with phytochemicals because it has an elevated antioxidant activity (150-166\% than the unfermented juice). The overall acceptability of the fermented date juice during cold storage was significantly higher than the unfermented juice. In addition, the probiotic fermented date juice using both strains showed a positive effect on larynx human cancer cell line (Hep-2). The obtained probiotic juice is an alternative functional beverage that can contribute to the available probiotic products.

\section{References}

Al-Alawi, R. A., Al-Mashiqri, J. H., Al-Nadabi, J. S. M., Al-Shihi, B. I., \& Baqi, Y. (2017). Date palm tree (Phoenix dactylifera L.): Natural products and therapeutic options. Frontiers in Plant Science, 23, 845-849. http://dx.doi.org/10.3389/fpls.2017.00845. PMid:28588600.

Aleid, S. M., Al-Jasass, F. M., \& El-Neshwy, A. A. (2018). U.S. Patent No. 9,980,501 B2. Washington, DC: U.S. Patent and Trademark Office.

Ali, M. R. (2018). Consumer acceptance of orange juice mixed with water mint leave extract. Recent Patents on Food, Nutrition \& Agriculture, 9(1), 50-54. http://dx.doi.org/10.2174/22127984096661710311141 59. PMid:29086705.
Al-Otaibi, M. M., Saleha, F. A., \& Al-Obaid, R. (2013). Effect of date syrup (dips) on growth and survival of probiotic bacteria in milk. International Journal of Dairy Science, 8(1), 12-20. http://dx.doi. org/10.3923/ijds.2013.12.20.

Azam, R., Ghafouri-Fard, S., Tabrizi, M., Modarressi, M. H., Ebrahimzadeh-Vesal, R., Daneshvar, M., Mobasheri, M. B., \& Motevaseli, E. (2014). Lactobacillus acidophilus and Lactobacillus crispatus culture supernatants down regulate expression of cancertestis genes in the MDA-MB-231 cell line. Asian Pacific Journal of Cancer Prevention, 15(10), 4255-4259. http://dx.doi.org/10.7314/ APJCP.2014.15.10.4255. PMid:24935380.

Baliga, M. S., Baliga, B. R. V., Kandathil, S. M., Bhat, H. P., \& Vayalil, P. K. (2011). A review of the chemistry and pharmacology of the date fruits (Phoenix dactylifera L.). Food Research International, 44(7), 1812-1822. http://dx.doi.org/10.1016/j.foodres.2010.07.004.

Barros, C. P., Guimaraes, J. T., Esmerino, E. A., Duarte, M. C. K. H., Silva, M. C., Silva, R., Ferreira, B. M., Sant'Ana, A. S., Freitas, M. Q., \& Cruz, A. G. (2020). Paraprobiotics and postbiotics: concepts and potential applications in dairy products. Current Opinion in Food Science, 32, 1-8. http://dx.doi.org/10.1016/j.cofs.2019.12.003.

Bekheet, S. A., \& El-Sharabasy, S. F. (2019). Date palm status and perspective in Egypt. In J. M. Al-Khayri, S. M. Jain \& D. V. Johnson (Eds.), Date palm genetics resources and utilization (pp. 75-123). USA: Springer Netherlands. http://dx.doi.org/10.1007/978-94-017-9694-1. 
Cam, M., Icyer, N. C., \& Erdogan, F. (2014). Pomegranate peel phenolics: Microencapsulation, storage stability and potential ingredient for functional food development. Lebensmittel-Wissenschaft + Technologie, 55(1), 117-123. http://dx.doi.org/10.1016/j.lwt.2013.09.011.

Campos, R. C., Martins, E. M., Pires, B. A., Peluzio, M. C., Campos, A. N., Ramos, A. M., Júnior, B. R., Martins, A. D., Silva, R. R., \& Martins, M. L. (2019). In vitro and in vivo resistance of Lactobacillus rhamnosus GG carried by a mixed pineapple (Ananas comosus L. Merril) and jussara (Euterpe edulis Martius) juice to the gastrointestinal tract. Food Research International, 116, 1247-1257. http://dx.doi. org/10.1016/j.foodres.2018.10.012. PMid:30716912.

Chen, J. J., Wang, R., Li, X. F., \& Wang, R. L. (2011). Bifidobacterium longum supplementation improved high-fat-fed-induced metabolic syndrome and promoted intestinal Reg I gene expression. Experimental Biology and Medicine, 236(7), 823-831. http://dx.doi.org/10.1258/ ebm.2011.010399. PMid:21685239.

Choi, S. S., Kim, Y., Han, K. S., You, S., Oh, S., \& Kim, S. H. (2006). Effects of Lactobacillus strains on cancer cell proliferation and oxidative stress in vitro. Letters in Applied Microbiology, 42(5), 452-458. http:// dx.doi.org/10.1111/j.1472-765X.2006.01913.x. PMid:16620202.

Costa, M. G., Fonteles, T. V., De Jesus, A. T., \& Rodrigues, S. (2013). Sonicated pineapple juice as substrate for $L$. casei cultivation for probiotic beverage development: process optimization and product stability. Food Chemistry, 139(1-4), 261-266. http://dx.doi.org/10.1016/j. foodchem.2013.01.059. PMid:23561104.

Dallal, M., Mojarrad, M., Baghbani, F., Jalal-Mardaneh, J., \& Salehipour, Z. (2015). Effects of probiotic Lactobacillus acidophilus and Lactobacillus casei on colorectal tumor cells activity (Caco-2). Archives in Iran Medicine, 18, 167-172. http://dx.doi.org/0151803/AIM.006.

Daneshi, M., Ehsani, M. R., Razavi, S. H., \& Labbafi, M. (2013). Effect of refrigerated storage on the probiotic survival and sensory properties of milk/carrot juice mix drink. Electronic Journal of Biotechnology, 16(5), 1-12. http://dx.doi.org/10.2225/vol16-issue5-fulltext-2.

Dimitrovski, D., Velickova, E., Langerholc, T., \& Winkelhausen, E. (2015). Apple juice as a medium for fermentation by the probiotic PCS 26 strain. Annals of Microbiology, 65, 1-10. http://dx.doi.org/10.1007/ s13213-015-1056-7.

Ejtahed, H. S., Angoorani, P., Soroush, A. R., Atlasi, R., HasaniRanjbar, S., Mortazavian, A. M., \& Larijani, B. (2019). Probiotics supplementation for the obesity management: a systematic review of animal studies and clinical trials. Journal of Functional Foods, 52, 228-242. http://dx.doi.org/10.1016/j.jff.2018.10.039.

El Sohaimy, S. A., Abdelwahab, A. E., Brennan, C. S., \& Aboul-enein, A. M. (2015). Phenolic content, antioxidant and antimicrobial activities of Egyptian date palm (Phoenix dactylifera L.) fruits. Australian Journal of Basic and Applied Sciences, 9, 141-147. http:// dx.doi.org/10.19071/fbiol.2017.v6.3154.

Eliane, M., Martins, F., Ramos, A. M., Vanzela, E. S., Stringheta, P. C., Pinto, C. L. O., \& Martins, J. M. (2013). Products of vegetable origin: a new alternative for the consumption of probiotic bacteria. Food Research International, 51(2), 764-770. http://dx.doi.org/10.1016/j. foodres.2013.01.047.

Food and Agriculture Organization of the United Nations - FAOSTAT. (2017). Crop production, statistics division. Rome: FAOSTAT. Retrieved from http://faostat.fao.org

Gan, R., Shah, N., Wang, M., Lui, W., \& Corke, H. (2016). Fermentation alters antioxidant capacity and polyphenol distribution in selected edible legumes. International Journal of Food Science \& Technology, 51(4), 875-884. http://dx.doi.org/10.1111/ijfs.13062.

Garriga, M., Almaraz, M., \& Marchiaro, A. (2017). Determination of reducing sugars in extracts of Undaria pinnatifida (harvey) algae by
UV-visible spectrophotometer (DNS method). Actas de Ingenieria, 3, 173-179.

Granato, D., Branco, G. F., Nazzaro, F., Cruz, A., \& Faria, J. A. (2010). Functional foods and nondairy probiotic food development: trends, concepts, and products. Comprehensive Reviews in Food Science and Food Safety, 9(3), 292-302. http://dx.doi.org/10.1111/j.15414337.2010.00110.x.

Grom, L. C., Rocha, R. S., Balthazar, C. F., Guimaraes, J. T., Coutinho, N. M., Barros, C. P., Pimentel, T. C., Venancio, E. L., Collopy, I. Jr., Maciel, P. M. C., Silva, P. H. F., Granato, D., Freitas, M. Q., Esmerino, E. A., Silva, M. C., \& Cruz, A. G. (2020). Postprandial glycemia in healthy subjects: which probiotic dairy food is more adequate? Journal of Dairy Science, 103(2), 1110-1119. http://dx.doi. org/10.3168/jds.2019-17401. PMid:31785881.

Guimaraes, J. T., Balthazar, C. F., Silva, R., Rocha, R. S., Graça, J. S., Esmerino, E. A., Silva, M. C., Sant'Ana, A. S., Duarte, M. C. K. H., Freitas, M. Q., \& Cruz, A. G. (2020). Impact of probiotics and prebiotics on food texture. Current Opinion in Food Science, 33, 38-44. http://dx.doi.org/10.1016/j.cofs.2019.12.002.

Hashemi, S. M. B., \& Mahmoodi, M. (2017). Fermentation of barberry juice to produce probiotic beverage. Current Nutrition and Food Science, 13, 204-211. http://dx.doi.org/10.2174/15734013136661 70118123128.

Hill, C., Guarner, F., Reid, G., Gibson, G. R., Merenstein, D. J., Pot, B., Morelli, L., Canani, R. B., Flint, H. J., Salminen, S., Calder, P. C., \& Sanders, M. E. (2014). The international scientific association for probiotics and prebiotics consensus statement on the scope and appropriate use of the term probiotic. Nature Reviews. Gastroenterology \& Hepatology, 11(8), 506-514. http://dx.doi. org/10.1038/nrgastro.2014.66. PMid:24912386.

Karasawa, K., Uzuhashi, Y., Hirota, M., \& Otani, H. (2011). A matured fruit extract of date palm tree (Phoenix dactylifera L.) stimulates the cellular immune system in mice. Journal of Agricultural and Food Chemistry, 59(20), 11287-11293. http://dx.doi.org/10.1021/ jf2029225. PMid:21936496.

Karbasi, M., Yarmand, M. S., \& Mousavi, M. (2015). Fermentation potential of Lactobacillus rhamnosus and Lactobacillus acidophilus in date syrup to develop a functional fermented beverage: a comparative study. Journal of Food Processing and Preservation, 39(6), 863-870. http://dx.doi.org/10.1111/jfpp.12297.

Khosravi, S., Safari, M., Emam-Djomeh, Z., \& Golmakani, M. T. (2019). Development of fermented date syrup using Kombucha starter culture. Journal of Food Processing and Preservation, 43(2), 1-10. http://dx.doi.org/10.1111/jfpp.13872.

Kumar, R. S., Kanmani, P., Yuvaraj, N., Paari, K. A., Pattukumar, V., Thirunavukkarasu, C., \& Arul, V. (2012). Lactobacillus plantarum AS1 isolated from south Indian fermented food Kallappam suppress 1,2-dimethyl hydrazine (DMH)-induced colorectal cancer in male Wister rats. Applied Biochemistry and Biotechnology, 166(3), 620631. http://dx.doi.org/10.1007/s12010-011-9453-2. PMid:22161238.

Kwak, S., Cho, Y., Noh, G., \& Om, A. (2014). Cancer preventive potential of kimchi lactic acid bacteria (Weissella cibaria, Lactobacillus plantarum). Journal of Cancer Prevention, 19(4), 253-258. http:// dx.doi.org/10.15430/JCP.2014.19.4.253. PMid:25574459.

Kwaw, E., Ma, Y., Tchabo, W., Apaliya, M. T., Wu, T., Sackey, A. S., Xiao, L., \& Tahir, H. E. (2018). Effect of Lactobacillus strains on phenolic profile, color attributes and antioxidant activities of lactic-acidfermented mulberry juice. Food Chemistry, 250, 148-154. http:// dx.doi.org/10.1016/j.foodchem.2018.01.009. PMid:29412905.

Kwaw, E., Ma, Y., Tchabo, W., Apaliya, M. T., Xiao, L., Li, X., \& Hu, M. (2017). Effect of fermentation parameters and their optimization 
on the phytochemical properties of lactic-acid-fermented mulberry juice. Journal of Food Measurement and Characteristics, 11(3), 14621473. http://dx.doi.org/10.1007/s11694-017-9525-2.

Marazza, J. A., Garro, M. S., \& Savoy de Giori, G. (2009). Aglycone production by Lactobacillus rhamnosus CRL981 during soymilk fermentation. Food Microbiology, 26(3), 333-339. http://dx.doi. org/10.1016/j.fm.2008.11.004. PMid:19269578.

Mohan, G., Guhankumar, P., Kiruththica, V., Santhiya, N., \& Anita, S. (2013). Probiotication of fruit juices by Lactobacillus acidophilus. International Journal of Advanced Biotechnology Research, 4, 935-940.

More, S. A., Patil, S. S., Kakanur, M., Thakur, R., Nayak, N., \& Kumar, R. (2018). A quantitative analysis of total carbohydrate content from the salivary expectorants in young children. Journal of the Indian Society of Pedodontics and Preventive Dentistry, 36(1), 53-57. http:// dx.doi.org/10.4103/JISPPD.JISPPD_153_17. PMid:29607840.

Mortazavian, A. M., Ghorbanipour, S., Mohammadifar, M. A., \& Mohammadi, M. (2011). Biochemical properties and viable probiotic population of yogurt at different bacterial inoculation rates and incubation temperatures. Philippine Agricultural Scientist, 94, 155-160.

Nazarni, R., Purnama, D., Umar, S., \& Eni, H. (2016). The effect of fermentation on total phenolic, flavonoid and tannin content and its relation to antibacterial activity in jaruk tigarun (Crataeva nurvala, Buch HAM). International Food Research Journal, 23, 309-315.

Othman, N. B., Roblain, D., Chammen, N., Thonart, P., \& Hamdi, M. (2009). Antioxidant phenolic compounds loss during the fermentation of Chetoui olives. Food Chemistry, 116(3), 662-669. http://dx.doi. org/10.1016/j.foodchem.2009.02.084.

Pereira, A. L. F., Almeida, F. D. L., Jesus, A. L. T., Costa, J. M. C., \& Rodrigues, S. (2013). Storage stability and acceptance of probiotic beverage from cashew apple juice. Food and Bioprocess Technology, 6(11), 3155-3165. http://dx.doi.org/10.1007/s11947-012-1032-1.

Pereira, A. L. F., Feitosa, W. S. C., Abreu, V. K. G., Lemos, T. O., Gomes, W. F., Narain, N., \& Rodrigues, S. (2017). Impact of fermentation conditions on the quality and sensory properties of a probiotic cupuassu (Theobroma grandiflorum) beverage. Food Research International, 100(Pt 1), 603-611. http://dx.doi.org/10.1016/j. foodres.2017.07.055. PMid:28873727.

Perricone, M., Bevilacqua, A., Altieri, C., Sinigaglia, M., \& Corbo, M. R. (2015). Challenges for the production of fruit juices. Beverages, 1(2), 95-103. http://dx.doi.org/10.3390/beverages1020095.

Pontonio, E., Montemurro, M., Pinto, D., Marzani, B., Trani, T., Ferrara, G., Mazzeo, A., Gobbetti, M., \& Rizzello, C. G. (2019). Lactic acid fermentation of pomegranate juice as a tool to Improve antioxidant activity. Frontiers in Microbiology, 10, 1-16. http://dx.doi.org/10.3389/ fmicb.2019.01550. PMid:31333636.

Rafiq, S., Gulzar, N., Huma, N., Hussain, I., \& Murtaza, M. S. (2020). Evaluation of anti-proliferative activity of Cheddar cheeses using colon adenocarcinoma (HCT-116) cell line. International Journal of Dairy Technology, 73(1), 255-260. http://dx.doi.org/10.1111/14710307.12665.

Rafiq, S., Huma, N., Gulzar, N., Murtaza, M. A., \& Hussain, I. (2018a). Effect of Cheddar cheese peptide extracts on growth inhibition, cell cycle arrest and apoptosis induction in human lung cancer (H-1299) cell line. International Journal of Dairy Technology, 71(4), 975-980. http://dx.doi.org/10.1111/1471-0307.12533.

Rafiq, S., Huma, N., Rakariyatham, K., Hussain, I., Gulzar, N., \& Hayat, I. (2018b). Anti-inflammatory and anticancer activities of watersoluble peptide extracts of buffalo and cow milk Cheddar cheeses. International Journal of Dairy Technology, 71(2), 432-438. http:// dx.doi.org/10.1111/1471-0307.12483.
Rahmani, A. H., Aly, S. M., Ali, H., Babiker, A. Y., Srikar, S., \& Khan, A. A. (2014). Therapeutic effects of date fruits (Phoenix dactylifera) in the prevention of diseases via modulation of anti-inflammatory, anti-oxidant and anti-tumor activity. International Journal of Clinical and Experimental Medicine, 7(3), 483-491. PMid:24753740.

Reddy, S. B., \& Rivenson, A. (1993). Inhibitory effect of Bifidobacterium longum on colon, mammary, and liver carcinogenesis induced by 2-amino-3-methylimidazo [4, 5-f-quinoline, a food mutagen. Cancer Research, 53(17), 3914-3918. PMid:8358717.

Rezazadeh, L., Gargari, B. P., Jafarabadi, M. A., \& Alipour, B. (2019). Effects of probiotic yogurt on glycemic indexes and endothelial dysfunction markers in patients with metabolic syndrome. Nutrition (Burbank, Los Angeles County, Calif.), 62, 162-168. http://dx.doi. org/10.1016/j.nut.2018.12.011. PMid:30921552.

Rijkers, G. T., de Vos, W. M., Brummer, R. J., Morelli, L., Corthier, G., \& Marteau, P. (2011). Health benefits and health claims of probiotics: bridging science and marketing. British Journal of Nutrition, 106(9), 1291-1296. http://dx.doi.org/10.1017/S000711451100287X. PMid:21861940.

Roobab, U., Batool, Z., Manzoor, M. F., Shabbir, M. A., Khan, M. R., \& Aadil, R. M. (2020). Sources, formulations, advanced delivery and health benefits of probiotics. Current Opinion in Food Science, 32, 17-28. http://dx.doi.org/10.1016/j.cofs.2020.01.003.

Roshan, H., Ghaedi, E., Rahmani, J., Barati, M., Najafi, M., Karimzedeh, M., \& Nikpayam, O. (2019). Effects of probiotics and synbiotic supplementation on antioxidant status: a meta-analysis of randomized clinical trials. Clinical Nutrition ESPEN, 30, 81-88. http://dx.doi. org/10.1016/j.clnesp.2019.02.003. PMid:30904233.

Ruas-Madiedo, P., \& De los Reyes-Gavilan, C. G. (2005). Invited review: methods for the screening, isolation, and characterization of exopolysaccharides produced by lactic acid bacteria. Journal of Dairy Science, 88(3), 843-856. http://dx.doi.org/10.3168/jds.S00220302(05)72750-8. PMid:15738217.

Salami, M., Kouchaki, E., Asemi, Z., \& Tamtaji, O. R. (2019). How probiotic bacteria influence the motor and mental behaviors as well as immunological and oxidative biomarkers in multiple sclerosis? A double blind clinical trial. Journal of Functional Foods, 52, 8-13. http://dx.doi.org/10.1016/j.jff.2018.10.023.

Sheehan, V. M., Ross, P., \& Fitzgerald, G. F. (2007). Assessing the acid tolerance and the technological robustness of probiotic cultures for fortification in fruit juices. Innovative Food Science \& Emerging Technologies, 8(2), 279-284. http://dx.doi.org/10.1016/j.ifset.2007.01.007.

Shori, A. B. (2016). Influence of food matrix on the viability of probiotic bacteria: A review based on dairy and non-dairy beverages. Food Bioscience, 13, 1-8. http://dx.doi.org/10.1016/j.fbio.2015.11.001.

Singleton, V. L., \& Rossi, J. A. (1965). Colorimetry of total phenolics with phosphomolybdic-phosphotungstic acid reagents. American Journal of Enology and Viticulture, 16, 144-158.

Tang, W., Xing, Z., Hu, W., Li, C., Wang, J., \& Wang, Y. (2016). Antioxidative effects in vivo and colonization of Lactobacillus plantarum MA2 in the murine intestinal tract. Applied Microbiology and Biotechnology, 100(16), 7193-7202. http://dx.doi.org/10.1007/s00253-016-7581-X. PMid:27178180.

Tang, Z.-X., Shi, L.-E., \& Aleid, S. M. (2013). Date fruit: chemical composition, nutritional and medicinal values, products. Journal of the Science of Food and Agriculture, 93(10), 2351-2361. http:// dx.doi.org/10.1002/jsfa.6154. PMid:23553505.

Vasconcelos, F. M., Silva, H. L. A., Poso, S. M. V., Barroso, M. V., Lanzetti, M., Rocha, R. S., Graca, J. S., Esmerino, E. A., Freitas, M. Q., Silva, M. C., Raices, R. S. L., Granato, D., Pimentel, T. C., Sant'Ana, A. S., Cruz, A. G., \& Valenca, S. S. (2019). Probiotic Prato 
cheese attenuates cigarette smoke-induced injuries in mice. Food Research International, 123, 697-703. http://dx.doi.org/10.1016/j. foodres.2019.06.001. PMid:31285019.

Vichai, V., \& Kirtikara, K. (2006). Sulforhodamine B, colorimetric assay for cytotoxicity screening. Nature Protocols, 1(3), 1112-1116. http:// dx.doi.org/10.1038/nprot.2006.179. PMid:17406391.

White, J., \& Hekmat, S. (2018). Development of probiotic fruit juices using Lactobacillus rhamnosus GR-1 fortified with short chain and long chain inulin fiber. Fermentations, 4(2), 1-12. http://dx.doi. org/10.3390/fermentation4020027.

Wijayanti, E. D., Setiawan, N. C. E., \& Christi, J. P. (2017). Effect of lactic acid fermentation on total phenolic content and antioxidant activity of fig fruit juice (Ficus carica). Advances in Health Science Research, 2, 282-289. http://dx.doi.org/10.2991/hsic-17.2017.44.

World Health Organization - WHO. (2018). Cancer. Geneva: WHO. Retrieved from https://www.who.int/news-room/fact-sheets/detail/ cancer

World Health Organization - WHO. (2019). The global cancer observatory-Egypt. Geneva: International Agency for Research on Cancer/WHO. Retrieved from http://gco.iarc.fr/today/data/ factsheets/populations/818-egypt-fact-sheets.pdf

Wu, S. C., Su, Y. S., \& Cheng, H. Y. (2011). Antioxidant properties of Lactobacillus-fermented and non-fermented Graptopetalum paraguayense E. Walther at different stages of maturity. Food Chemistry, 129(3), 804-809. http://dx.doi.org/10.1016/j.foodchem.2011.05.025. PMid:25212302.

Yahyaoui, A. G., Aydi, A., Bouzaiene, T., \& Hamdi, M. (2017). Traditional cereal food as container of probiotic bacteria (Lb. rhamnosus GG): Optimization by response surface methodology. Journal of Food Quality, 1742143, 1-12. http://dx.doi.org/10.1155/2017/1742143.

Yu, A. Q., \& Li, L. (2016). The potential role of probiotics in cancer prevention and treatment. Nutrition and Cancer, 68(4), 535-544. http://dx.doi.org/10.1080/01635581.2016.1158300. PMid:27144297.

Zhang, Z. C., Soccol, A., \& Pandey, A. (2012). Production of powerful antioxidant supplements via solid-state fermentation of wheat (Triticum aestivum Linn.). Food Technology and Biotechnology, 50, 32-39.

Zucko, J., Starcevic, A., Diminic, J., Oros, D., Mortazavian, A. M., \& Putnik, P. (2020). Probiotic-friend or foe? Current Opinion in Food Science, 32, 45-49. http://dx.doi.org/10.1016/j.cofs.2020.01.007. 


\section{Supplementary material}

Supplementary material accompanies this paper.

Figure 1. Characterization of phenolic compounds of unfermented date juice (control) using HPLC.

Figure 2. Characterization of phenolic compounds of fermented date juice by L. acidophilus using HPLC.

Figure 3. Characterization of phenolic compounds of fermented date juice by L. sakei using HPLC.

This material is available as part of the online article from http://www.scielo.br/CTA 